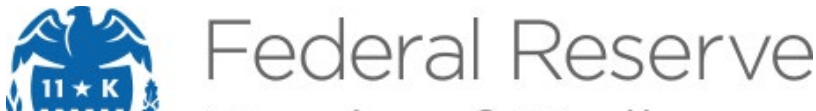 Bank of Dallas
}

\section{How Foreign- and U.S.-Born Latinos Fare During Recessions and Recoveries}

Pia M. Orrenius and Madeline Zavodny

This paper was prepared for a special issue of The ANNALS of the American Academy of Political and Social Science, "What has happened to the American Working Class since the Great Recession?"

\section{Working Paper 2104}

\section{April 2021}

Research Department

https://doi.org/10.24149/wp2104

Working papers from the Federal Reserve Bank of Dallas are preliminary drafts circulated for professional comment. The views in this paper are those of the authors and do not necessarily reflect the views of the Federal Reserve Bank of Dallas or the Federal Reserve System. Any errors or omissions are the responsibility of the authors. 


\title{
How Foreign- and U.S.-Born Latinos Fare During Recessions and Recoveries*
}

Pia M. Orrenius ${ }^{\dagger}$ and Madeline Zavodny ${ }^{\ddagger}$

March 2021

\begin{abstract}
Latinos make up the nation's largest ethnic minority group. The majority of Latinos are U.S. born, making the progress and well-being of Latinos no longer just a question of immigrant assimilation but also of the effectiveness of U.S. educational institutions and labor markets in equipping young Latinos to move out of the working class and into the middle class. One significant headwind to progress among Latinos is recessions. Economic outcomes of Latinos are far more sensitive to the business cycle than are outcomes for non-Hispanic whites. Latinos also have higher poverty rates than whites, although the gap had been falling prior to the pandemic. Deep holes in the pandemic safety net further imperiled Latino progress in 2020 and almost surely will in 2021 as well. Policies that would help working-class and poor Latinos include immigration reform and education reform and broader access to affordable health care.
\end{abstract}

Keywords: Hispanics, immigrants, working class, business cycle

JEL Codes: J11, J15, E24

\footnotetext{
* This paper was prepared for a special issue of The ANNALS of the American Academy of Political and Social Science, "What has happened to the American Working Class since the Great Recession?" Authors thank Jennifer Romich, Michael Strain, and Timothy Smeeding, and participants in the January 2021 ANNALS special issue workshop for helpful comments. The views expressed are those of the authors and do not reflect those of the Federal Reserve Bank of Dallas or Federal Reserve System.

${ }^{\dagger}$ Pia M. Orrenius, Federal Reserve Bank of Dallas, 2200 N. Pearl St., Dallas, TX 75201 and IZA, pia.orrenius@dal.frb.org.

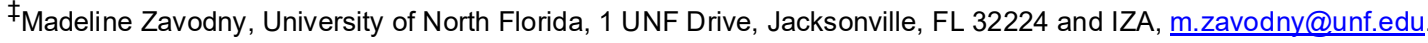


The cliché that "a rising tide lifts all boats" appears to hold true for Latinos in the United States. ${ }^{2}$ Most Latinos see their economic fortunes rise during periods of economic growth, and at a faster pace than among non-Hispanic whites. Conversely, Latinos tend to incur larger losses than whites during recessions, especially foreign-born Latinos (Orrenius and Zavodny 2010, 2013a). This article examines how Latinos have fared in the United States since 1994, a period that witnessed dramatic changes in the macroeconomy. We focus on how prime-aged Latino workers and their families did as the U.S. economy experienced robust expansions, deep downturns, and sluggish recoveries. We pay particular attention to the working class, defined here as families with a prime-aged head that are in the second through fourth deciles of the income distribution.

Latinos are the largest minority group in the United States, making it important to understand their economic well-being across the business cycle. Many Latinos are also immigrants, which means their progress relates intimately to immigrant assimilation. The Latino population is increasingly diverse along many dimensions. It is no longer dominated by Mexican-born male workers with little formal education and low wages who are clustered in a few gateway states and labor-intensive sectors. Over the past 25 years, Latino immigration has included larger streams from countries other than Mexico as well as both asylum seekers and high-skilled professionals. At the same time, many established Latino families moved out of poverty and into the working class or from the working class into higher income groups. This upward movement occurred amidst a backdrop of economic growth interrupted by the Great Recession and now threatened by the Covid-19 collapse.

This article begins with a brief overview of the Latino population and then takes a deeper look at Latinos' progress over time, taking stock of the impact of the Great Recession and the pandemic-induced downturn. We consider labor market outcomes and trends in poverty rates and highlight the holes in the

\footnotetext{
${ }^{2}$ We use the terms Hispanic and Latino interchangeably. We classify people as Latinos if they are identified as Hispanic in the Current Population Survey (CPS) or if they or a parent are from Latin America, Cuba, or the Dominican Republic. Latinos can be of any race. We classify people as non-Hispanic whites if they are identified in the CPS as white and non-Hispanic and neither they nor a parent are from Latin America, Cuba, or the Dominican Republic. Hispanic is an ethnic classification, not a racial classification, and ethnicity trumps race in our classification scheme.
} 
pandemic safety net that will likely set many Latinos, including but not limited to those in the working class, back for several years. We then discuss policy actions that would be most helpful to working-class and poor Latinos, including immigration and education reforms and expanded access to health insurance.

\section{A Snapshot of Latinos}

Latinos have been the principal driver of U.S. population growth in recent decades, causing their share of the population to dramatically rise. As Figure 1 shows, Latinos now account for almost one-fifth of the prime-aged (ages 25-59) U.S. population and over one-quarter of children ages 0-17. With Latinos the largest racial/ethnic minority and such a large fraction of children, the country's future will in part depend on how well Latinos do. That said, growth in the Latino population has slowed since the Great Recession as a consequence of less immigration and falling birth rates.

\section{FIGURE 1}

\section{Latinos Are the Largest Minority Group in the United States}
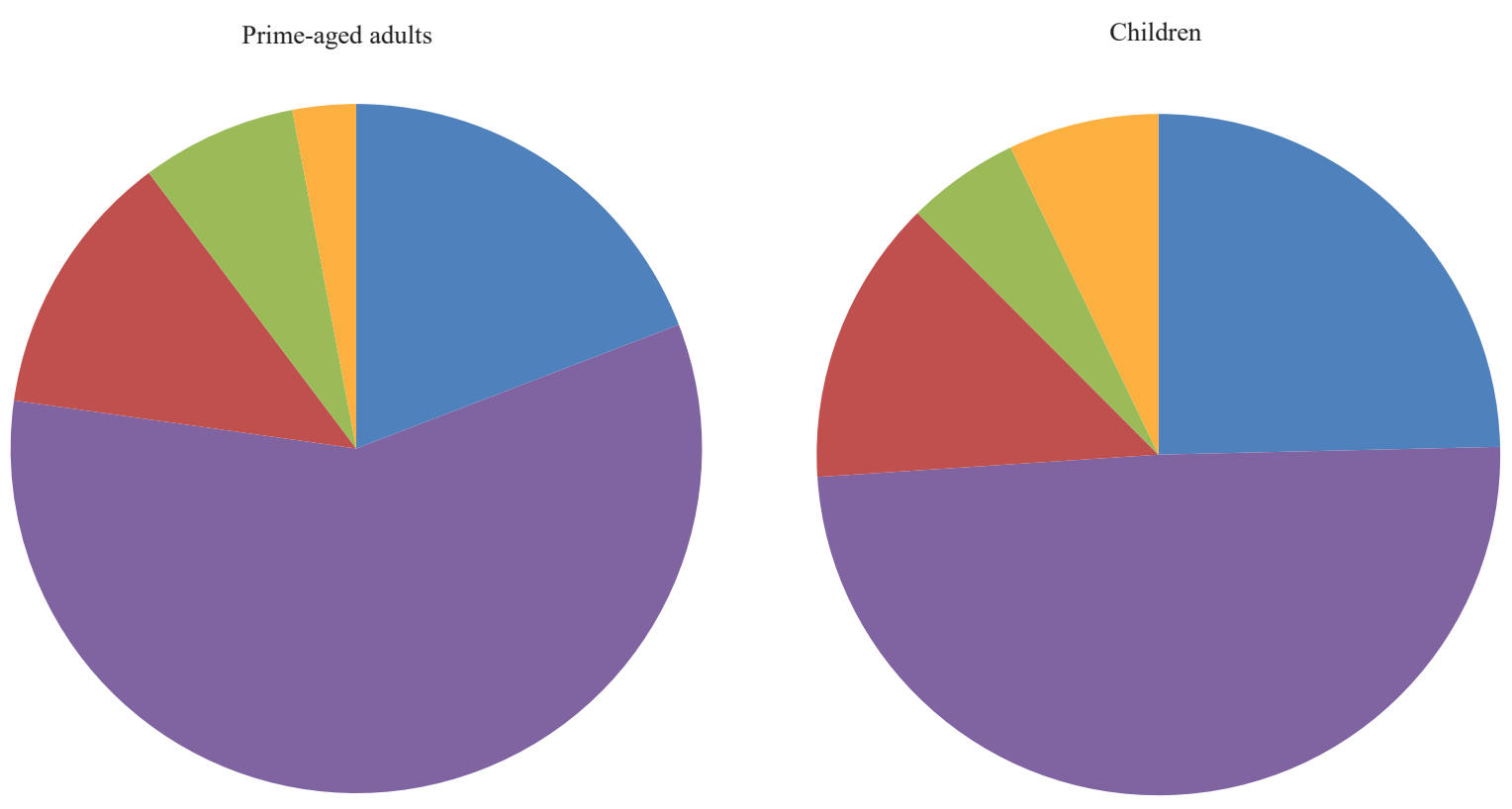

$\square$ Latino $\quad$ White $\quad$ Black $\quad$ Asian $\quad$ Other (incl. multiracial)

NOTE: Authors' calculations using 2020 CPS ASEC data from IPUMS. 
It may come as a surprise that most Latinos are U.S. natives. ${ }^{3}$ Immigrants account for about onethird of U.S. Latinos. But because of differences in the age structure of foreign- and U.S.-born Latinos, immigrants make up a slight majority of the Latino workforce.

TABLE 1

Latinos Have Less Education, Larger Households, Lower Income than Non-Hispanic Whites

\begin{tabular}{lccc}
\hline & \multicolumn{2}{c}{ Hispanic } & \multirow{2}{*}{$\begin{array}{c}\text { Non-Hispanic } \\
\text { white }\end{array}$} \\
\cline { 2 - 3 } & Immigrant & U.S. native & 42.5 \\
Age & 42.8 & 38.2 & 0.63 \\
Married & 0.67 & 0.49 & 0.50 \\
Male & 0.48 & 0.47 & -- \\
Mexican-descent & 0.57 & 0.68 & \\
Highest education level: & & & 0.04 \\
Less than high school graduate & 0.36 & 0.10 & 0.24 \\
High school graduate & 0.31 & 0.31 & 0.27 \\
Some college & 0.15 & 0.32 & 0.45 \\
Bachelor's degree or higher & 0.18 & 0.27 & 3.0 \\
Number of hhld members & 3.9 & 3.5 & 0.41 \\
Number of children in hhld & 0.59 & 0.50 & $\$ 104,458$ \\
Household income previous year & $\$ 63,602$ & $\$ 81,741$ & \\
\hline
\end{tabular}

NOTE: Authors' calculations using 2020 CPS ASEC data from IPUMS. Only prime-aged adults are included. Median household income is shown; the other variables are means or shares.

Table 1 reports characteristics of prime-aged Latinos by immigrant status, plus non-Hispanic whites for comparison. Latinos tend to have completed less education than non-Hispanic whites. ${ }^{4}$ They live in larger households and have more children. Household income is lower, on average. With the exception of the share who are married, all of these differences relative to non-Hispanic whites are bigger for immigrants than for U.S. natives.

\footnotetext{
${ }^{3}$ We classify people born in Puerto Rico as U.S. natives. They comprise about one-eighth of U.S.-native Latinos in our sample. Our analysis only includes Puerto Ricans who have moved to the mainland United States.

${ }^{4}$ Selection in who identifies as Hispanic is an important consideration. As noted by Duncan and Trejo (2018a), there is negative selection in Hispanic self-identification among U.S. natives. This selection bias widens the gaps we find between Hispanic and non-Hispanic white natives. We do not address racial differences among Latinos, which are another important consideration.
} 


\section{Latinos More Likely to be Working Class}

As suggested by the differences in median household income in Table 1, Hispanic households tend to be lower in the income distribution than non-Hispanic white households. Figure 2 shows the distribution of households headed by a prime-aged Latino (by nativity) or non-Hispanic white across deciles of the 2019 income distribution. ${ }^{5}$ If a group has the same income distribution as the population as a whole, 10 percent of that group would be in each decile. Instead, Latino households are over-represented in the bottom half of the income distribution. Non-Hispanic white households are more evenly distributed than Latino households, but their share rises across deciles.

FIGURE 2

\section{Latino Immigrant Households Are More Likely to be at Bottom of the Income Distribution}

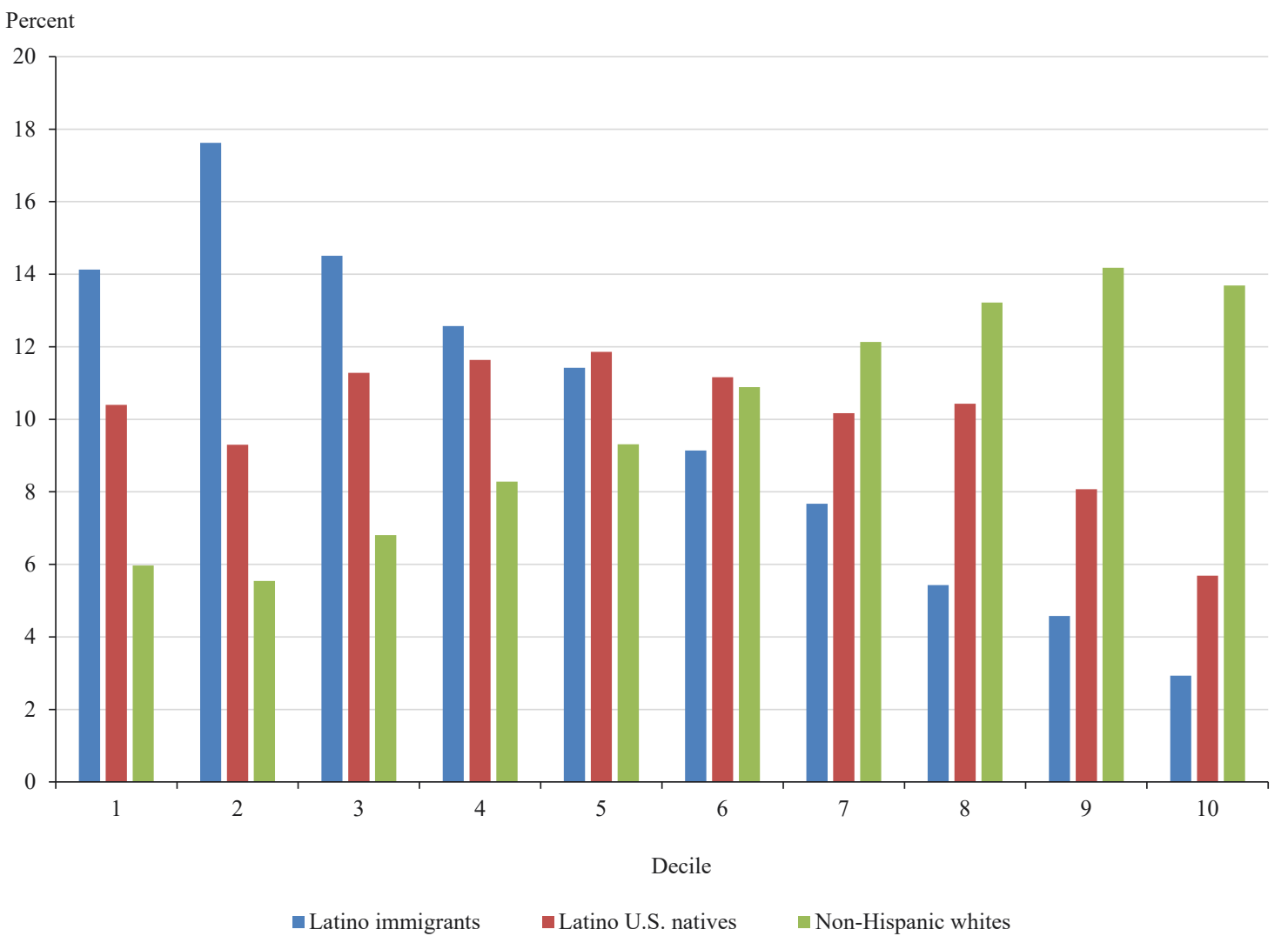

NOTE: Shown is the distribution of households with a head in the indicated group. Only households with a prime-aged head (age 25-59) are shown, but the income thresholds for the deciles are created using all households. Authors' calculations from 2020 CPS ASEC data from IPUMS using household income for the previous calendar year.

\footnotetext{
${ }^{5}$ Income deciles are created based on total household income adjusted for the number of people in the household (we divide total income by the square root of the number of people). Like all calculations here involving households, the data were weighted using the ASEC household weights to make the sample nationally representative. Incomes are for the previous calendar year.
} 
Latino households are considerably more likely than non-Hispanic white households to be working class or poor. We define the working class as households with income between the $10^{\text {th }}$ and $40^{\text {th }}$ percentiles of the income distribution (deciles 2-4 in the figure) to avoid classifying the poorest households as working class; we do not consider education since it is a relatively weak indicator of position in the income distribution for Hispanics. Almost half of households headed by a Latino immigrant are working class, and one-third of households headed by a Latino native. Latino households, especially those headed by an immigrant, also are more likely to be in the bottom decile.

Why are Latino households clustered in the bottom half of the income distribution? Low levels of education are a key factor, along with limited ability to speak English for many Hispanic immigrants (Orrenius and Zavodny 2013b). Importantly, not working is not a reason why Latino household incomes are relatively low. Low-income Latino households are more likely than non-Hispanic whites to be headed by someone who has a job. Age differences are one reason for the employment gap since Latinos tend to be younger, but higher Latino employment among low-income households holds true even among primeaged household heads. ${ }^{6}$

\section{Latino Immigrant Income Assimilation}

Because so many Latinos are immigrants and come to the United States to start a new life, it's likely they start at the bottom. But do they work their way up over time? The evidence indicates they do-Hispanic immigrants' earnings rise toward those of the average U.S. native over the first two or three decades they are in the United States, although relative progress then appears to stall out (Peri and Rutledge 2020). Much of the progress is likely the result of learning some English and making better job matches over time. There is also intergenerational progress between Hispanic immigrants and their children, as Figure 2 suggests and other research corroborates (National Academies of Sciences, Engineering, and Medicine 2015). However, relatively low levels of education prevent U.S.-born Latinos from fully catching up with

\footnotetext{
${ }^{6}$ In 2020 CPS ASEC data, 63 percent of prime-aged Latino heads of households in $1^{\text {st }}$ through $4^{\text {th }}$ deciles of the income distribution are employed, versus 58 percent of corresponding non-Hispanic whites.
} 
their non-Hispanic white counterparts in terms of employment or earnings (Orrenius and Zavodny 2019; Duncan and Trejo 2018b).

Latino households moved up in the income distribution over the past two decades. Figure 3 shows the relative change between 1997-99 and 2017-19 in the share of prime-aged Latino households, by nativity, in each decile of the income distribution. ${ }^{7}$ The first period includes the peak of the $1990 \mathrm{~s}$ expansion, while the second includes the peak of the 2010s expansion. The drop in the representation of Latino households in the lowest deciles is impressive. The share of Latino households in the lowest income decile fell by about 50 percent. Latino immigrant households also moved out of the second and third deciles. The gains come despite the fact that Hispanic immigrants failed to make relative earnings gains during the first decade of the 2000s because of the Great Recession (Peri and Rutledge 2020). One caveat to this analysis is that the comparison is based on two cross-sections of data, so they do not follow the same households over time. More positive selection among Hispanic immigrants over time might be contributing to the apparent upward mobility.

Differences in wealth are much larger than income disparities. Average net worth of nonHispanic white families was five times that of Hispanic families in 2019, a substantial gap but down from a six-fold gap in $2013 .{ }^{8}$ The gap in average family net worth between Hispanics and non-Hispanic whites tends to shrink during economic expansions and grow during recessions (Thompson and Suarez 2017). Addo and Darity (2021) further discuss wealth gaps by race and ethnicity.

\footnotetext{
${ }^{7}$ The changes are computed as the difference over time in the share of households in each decile that are Latino divided by the share of all households that are Latino, by nativity.

${ }^{8}$ Based on Thompson and Suarez (2017) and https://www.federalreserve.gov/econres/notes/feds-notes/disparitiesin-wealth-by-race-and-ethnicity-in-the-2019-survey-of-consumer-finances-20200928.htm.
} 
FIGURE 3

Latino Households Moved out of Bottom of the Income Distribution over the Last Two Decades Percent

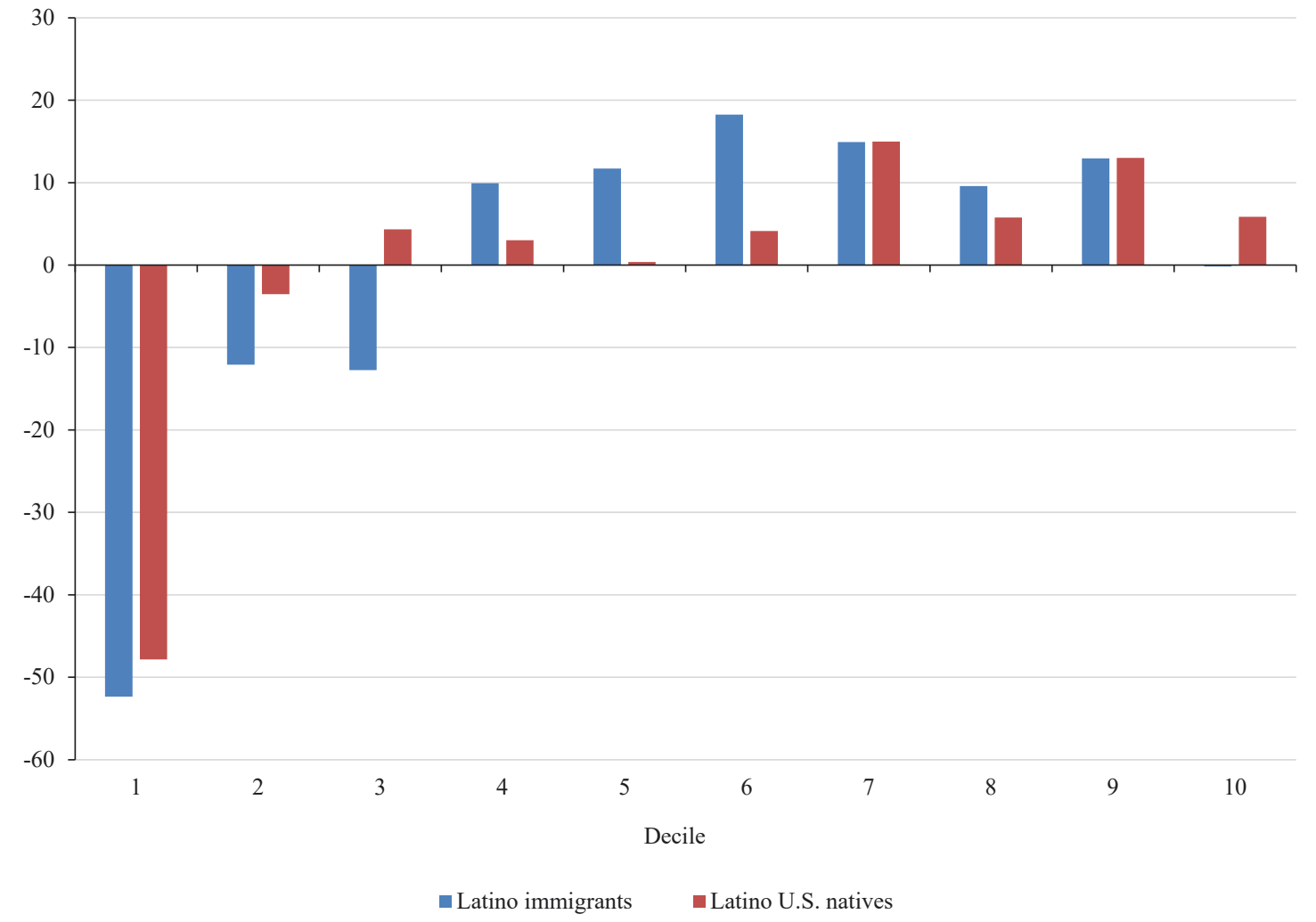

NOTE: Shown is the relative change of the share of households in each decile of the income distribution with a prime-aged head in the indicated group. Authors' calculations from March 1998-2000 and 2018-2020 CPS ASEC data from IPUMS using household income for the previous calendar year.

The key question now is, will the pandemic and resultant recession derail this progress and have as adverse an impact on Latinos as the Great Recession did, or even worse? To examine this, we turn to a comparison of Latinos' and non-Hispanic whites' employment, unemployment, wages, and poverty rates over the business cycle. We show results here for all prime-aged Latinos, and results for those in the working class are available in the online appendix. ${ }^{9}$

\footnotetext{
${ }^{9}$ Because we define working class based on the household's position in the income distribution the previous calendar year, those results are available only for March of each year.
} 


\section{Latinos in the Labor Market}

As a whole, Latinos have lower employment rates and higher unemployment rates than non-Hispanic whites. ${ }^{10}$ In addition, job-holding is more sensitive to the business cycle among Hispanics than among non-Hispanic whites. Figures 4 and 5 show, respectively, employment and unemployment rates among prime-aged Latino immigrants and natives and non-Hispanic whites. ${ }^{11}$ Business-cycle effects are immediately apparent for all groups, with employment rates falling during recessions (the shaded areas) and rising during expansions, and unemployment rates doing the converse. The cyclical swings are much larger for Latinos, particularly immigrants, than for non-Hispanic whites. Further, the gaps between Latinos and non-Hispanic whites tend to narrow over the course of an economic expansion. Indeed, before the pandemic, Latino immigrants' unemployment rates had reached those of non-Hispanic whites. Conversely, the gaps widen considerably during recessions and their immediate aftermath. Other research similarly reports that labor market outcomes are more cyclically sensitive, especially to downturns, for Hispanics than for non-Hispanic whites (e.g., Couch, Fairlie, and Xu 2018; Aaronson et al. 2019).

\footnotetext{
${ }^{10}$ The employment deficit among Latinos vis-à-vis non-Hispanic whites is largely due to lower employment (and higher unemployment) among Latino women. Latino immigrant men have higher employment (and typically lower unemployment) than non-Hispanic white men.

${ }^{11}$ Calculations are based on CPS basic monthly data from IPUMS for people ages 25-59. We classify people as employed if they are at work or have a job but were not at work last week. Including the latter as employed reduces and spreads out over time the observed changes after March 2020 but does not affect the underlying pattern of the data. The NBER had not yet announced when the trough of the 2020 was reached as of February 2021. Our figures show it as May 2020 based on patterns of changes in the labor market and output.
} 
FIGURE 4

Employment is More Cyclical among Latinos

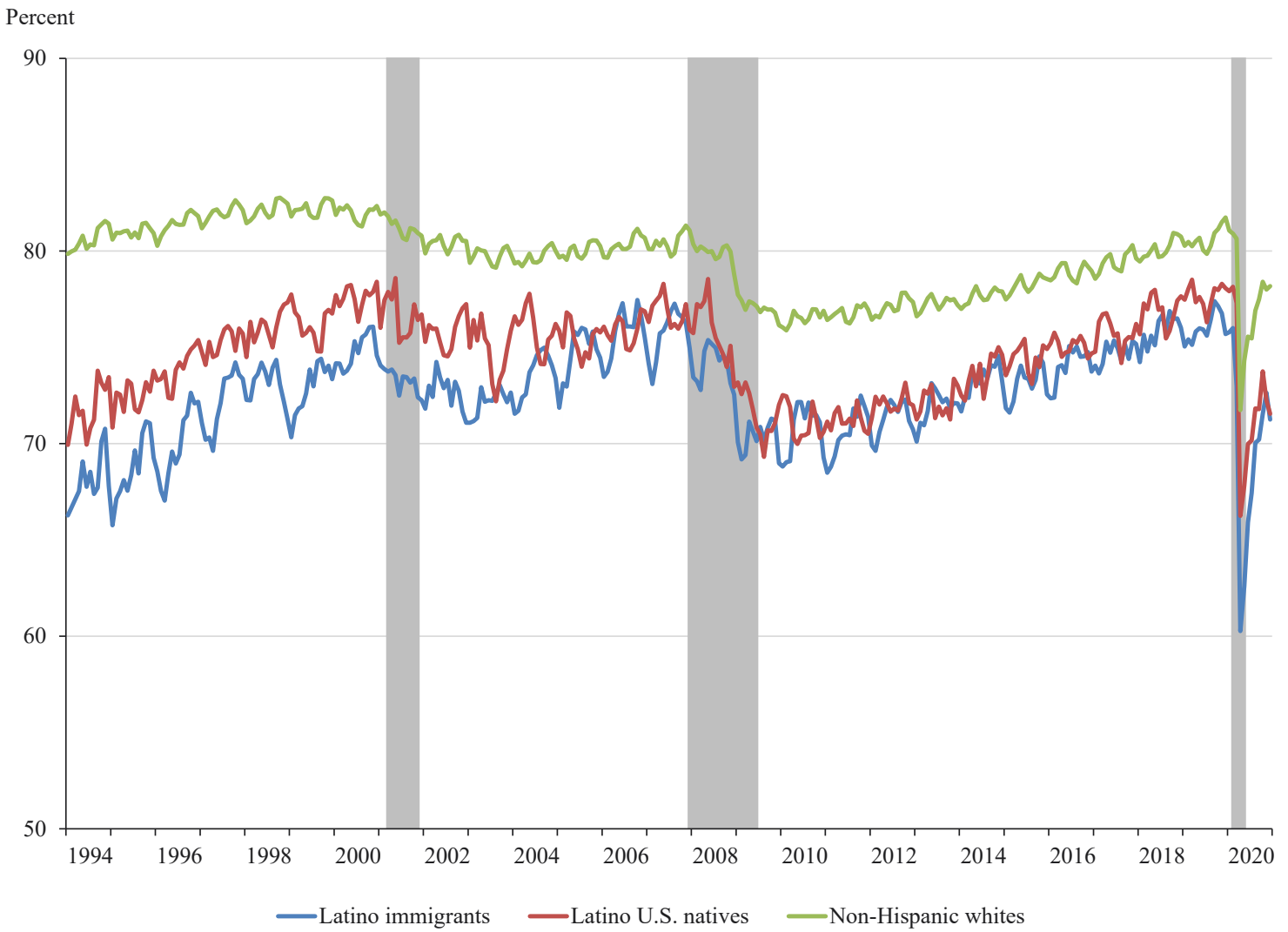

NOTE: Shown is the share of civilian adults ages 25-59 who are employed. Authors' calculations using January 1994-December 2020 CPS basic monthly files data from IPUMS. 
FIGURE 5

Unemployment Rates Are Even More Cyclical for Latinos

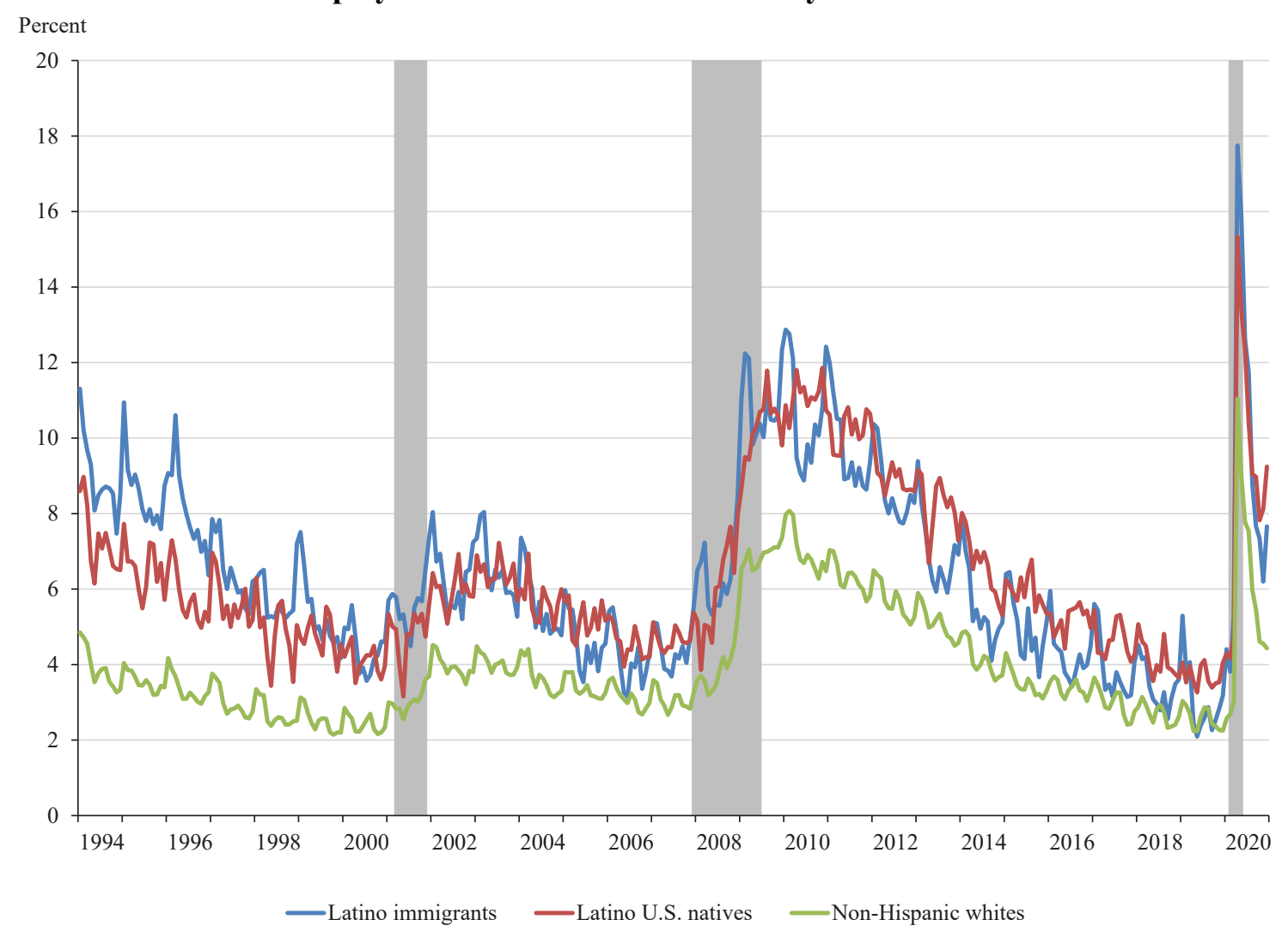

NOTE: Shown is the share of civilian adults ages 25-59 who are unemployed, conditional on being in the labor force. Authors' calculations using January 1994-December 2020 CPS basic monthly files data from IPUMS.

Lower average levels of education are a major reason Latinos, especially immigrants, have more cyclical labor market outcomes than non-Hispanic whites (Orrenius and Zavodny 2010, 2013a). Employers typically lay off low-skilled workers before they dismiss high-skilled employees in a recession. However, the difference in cyclical sensitivity occurs even within education groups. The difference in cyclical sensitivity also reflects differences in industry and occupation distributions and employer characteristics. Latinos, again particularly immigrants, tend to be clustered in sectors that are more cyclically sensitive. During the 1990s and 2000s, swings in the construction sector played an important role in Latino men's labor market outcomes. The Covid-19 crash hit Hispanics harder because of their over-representation in the hotel and restaurant industries and other jobs that cannot be done at home (Borjas and Cassidy 2020; Fairlie, Couch, and Xu 2020; Montenovo et al. 2020). Latinos are more 
likely to work for small businesses, and Latino immigrants are also more likely to be self-employed, both groups that are more exposed to business cycles. Differences in where Latinos and non-Hispanic whites live play relatively little role in the cyclical differences, in contrast.

Lack of legal status among many Latino immigrants likely also plays a role in the strong cyclicality of their labor market outcomes. Immigrants who lack legal status may be particularly vulnerable to recessions since they may have the most difficulty finding an employer willing to hire them, especially when available workers far exceed the number of jobs available. Unauthorized immigrant men were hit particularly hard by the Great Recession and the Covid-19 collapse (Orrenius and Zavodny 2010; Borjas and Cassidy 2020).

All of the above patterns are muted or even reversed when looking at just at prime-aged adults in working-class households. As Appendix Figures 2 and 3 show, working-class Latinos tend to fare just as well or better as whites in terms of employment and unemployment. This pattern is not surprising, however, since our definition of working class is based on household income. Given their lower levels of education, immigrant Latino households likely require more working adults to make it into the working class. Consistent with this, Appendix Figures 4 and 5 show lower median hourly earnings for Latino immigrants than for whites, regardless of whether we examine the working class or all workers.

\section{Poverty among Latinos}

Poverty among Hispanics is relatively high but has been on a downward trend, helped by the long economic expansions of the 1990s and 2010s. As Figure 6 shows, Hispanic households are more likely to be poor than non-Hispanic white households, and the gap is larger for households headed by a Hispanic immigrant than for those headed by a Hispanic U.S. native. Nonetheless, a considerable share of Hispanic households moved out of poverty during the 1990s and 2010s expansions, and Hispanic poverty rates moved toward those of non-Hispanic whites. (Similar patterns hold for working-class households, as

Appendix Figure 6 shows.) The apparent progress during the 2010s among immigrant households was 
boosted by smaller immigrant inflows from Mexico since new immigrants have particularly high poverty rates.

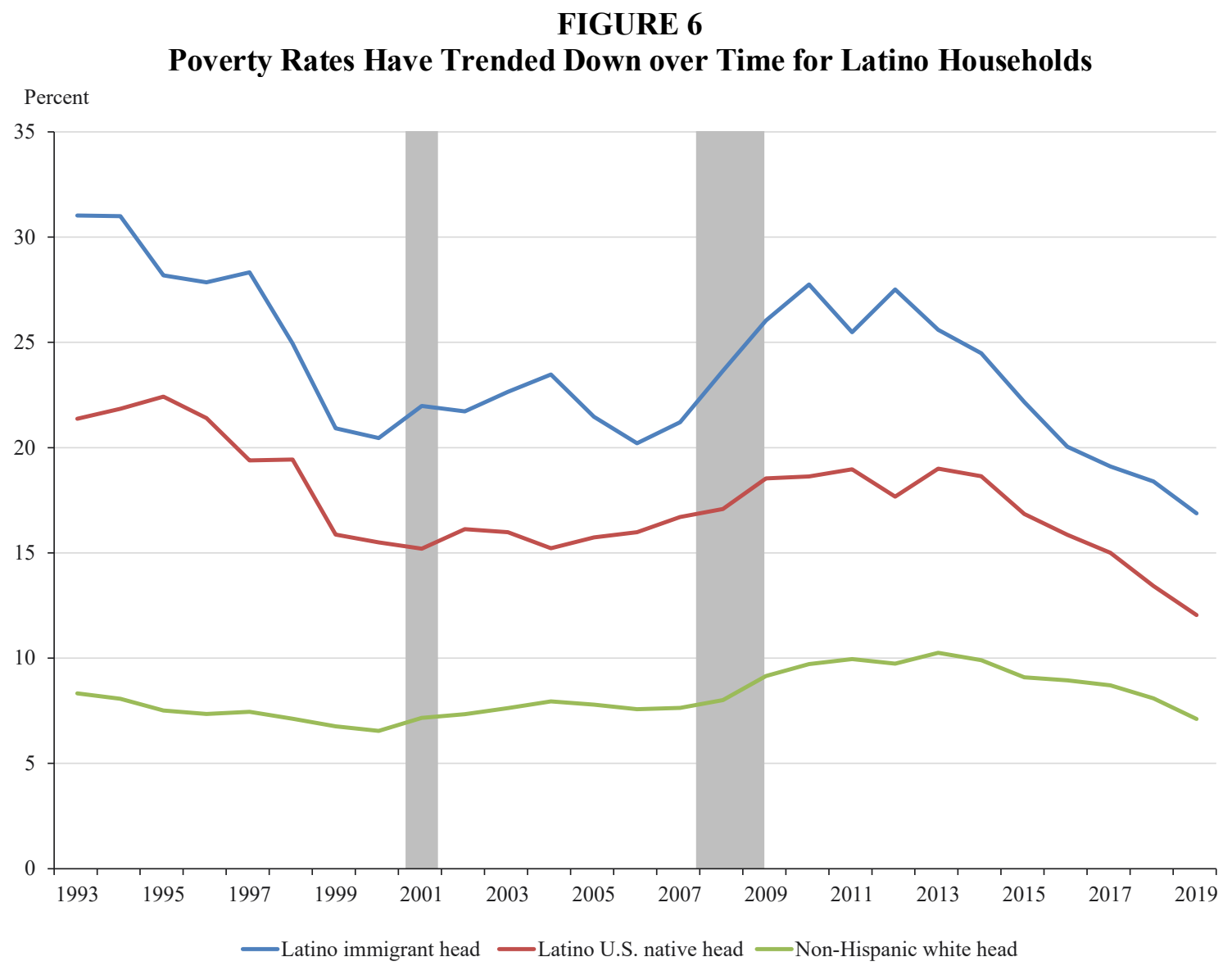

NOTE: Shown is the share of households with a prime-aged head in the indicated group classified as poor based on federal poverty guidelines. Authors' calculations from 1994-2020 CPS ASEC data from IPUMS using household income for the year indicated (the calendar year prior to the ASEC survey year).

Whether a household with a prime-aged head is poor depends in large part on whether adults in the household are working. However, there are a considerable number of "working poor" households, many of which are Hispanic. For working poor households, poverty results from some combination of not enough work, low hourly earnings, and a large household size. Whether a household falls under the federal poverty line depends on its pre-tax money income and its size, so larger households are more likely to be poor, all else equal. ${ }^{12}$ This contributes to Hispanics' relatively high poverty rates, but low

\footnotetext{
${ }^{12}$ The earned income tax credit (EITC) is an important supplement to family incomes for low-income workers with children and is not included when determining whether a household is poor. Unauthorized immigrant workers are not eligible for the EITC, although they are eligible for refundable child tax credits for U.S.-born children. The gap between the poverty rates of Hispanics and non-Hispanic whites widens when using the Supplemental Poverty
} 
hourly earnings probably play a bigger role. Again, not working is not the main reason Hispanic households have low incomes.

Nonetheless, not working means poverty for most working-age Hispanic households. Hispanic households have less savings and fewer assets to fall back on during periods of unemployment than nonHispanic white households. ${ }^{13}$ Hispanic immigrant-headed households also are less likely to access safety net programs, whose importance rises in economic downturns when jobs are scarce. Lack of legal status plays an important role. Unauthorized immigrants are ineligible for virtually all safety net programs, including cash welfare, food stamps, and unemployment insurance. In addition, mixed-status households that have both unauthorized immigrants and U.S. natives — who are typically children — are often unwilling to take-up benefits for which they are eligible for fear of revealing the presence of unauthorized immigrant members to the government or jeopardizing their future ability to gain legal status. When immigration enforcement rises, these fears are more prevalent and safety net program participation falls (Watson 2014; Alsan and Yang 2018). Revisions to the "public charge" rule in 2020 that make it harder for the foreign born to receive legal permanent resident status if they ever participated in transfer programs are likely to reduce Hispanic immigrant households' participation even further.

The double-whammy of not working and no safety net bodes poorly for how Hispanic households, especially those with unauthorized immigrants, have fared during the Covid-19 pandemic. Eligible immigrants concerned about the changes to the public charge rule may have been reluctant to take up benefits even as unemployment rates soared. Further, efforts to expand the safety net deliberately excluded unauthorized immigrants — not only were unauthorized immigrants ineligible for the CARES Act cash payments, but legal immigrants and U.S. citizens who filed taxes with an unauthorized

Measure that accounts for most government transfer programs (see https://www.census.gov/library/publications/2019/demo/p60-268.html, accessed July 17, 2020).

${ }^{13}$ See https://www.federalreserve.gov/econres/notes/feds-notes/recent-trends-in-wealth-holding-by-race-andethnicity-evidence-from-the-survey-of-consumer-finances-20170927.htm and https://www.federalreserve.gov/publications/2020-economic-well-being-of-us-households-in-2019-executivesummary.htm (accessed August 3, 2020). 
immigrant spouse were also ineligible initially. ${ }^{14}$ Laid-off unauthorized immigrants are not eligible for state unemployment insurance benefits, so those unemployed workers also missed out on supplemental unemployment benefits during the pandemic. ${ }^{15}$ But even U.S.-citizen Hispanics experienced gaps in the pandemic safety net: Hispanic families composed only of U.S. citizens were less likely to receive a CARES Act cash payment than non-Hispanic white families. ${ }^{16}$

A variety of other indicators point to the financial struggles that many poor and working-class Latino families face. Hispanics are less likely to have health insurance than any other large racial/ethnic group. In 2019, one in six Hispanics lacked health insurance, versus one in 20 non-Hispanic whites and one in 10 non-Hispanic blacks. ${ }^{17}$ That same year, one in six Hispanic-headed households experienced food insecurity, or not being certain they could afford adequate food to meet their needs. ${ }^{18}$ About onequarter of Hispanic adults who do not have a bachelor's degree (or higher) said in 2019 that they were unable to fully pay their current month's bills, and another fifth would not be able to pay their bills if faced with a $\$ 400$ emergency. ${ }^{19}$

Covid-19 has had a disproportionate impact on Latino households. Hispanics are more likely than non-Hispanics, either white or black, to live in overcrowded housing, which is determined based on the ratio of people to bedrooms or on square footage per person. ${ }^{20}$ This overcrowding, along with multigenerational households, contributed to the disproportionate spread of Covid-19 among Hispanics since infected people typically cannot isolate in overcrowded households. Lack of health insurance and

\footnotetext{
${ }^{14}$ The latter became eligible retroactively in the Coronavirus Response and Relief Supplemental Appropriations Act of 2021.

${ }^{15}$ Of course, not all unauthorized immigrant workers pay taxes or work "on the books" for employers; estimates suggest that about half of unauthorized immigrants pay income and payroll taxes (Congressional Budget Office, 2007).

${ }^{16}$ See https://www.taxpolicycenter.org/publications/who-did-not-get-economic-impact-payments-mid-late-may-andwhy/full (accessed August 2, 2020).

${ }^{17} \mathrm{See}$ https://www.census.gov/library/publications/2020/demo/p60-271.html (accessed October 4, 2020).

${ }^{18} \mathrm{See}$ https://www.ers.usda.gov/topics/food-nutrition-assistance/food-security-in-the-us/key-statistics-graphics.aspx (accessed August 2, 2020).

${ }^{19} \mathrm{See}$ https://www.federalreserve.gov/publications/2020-economic-well-being-of-us-households-in-2019-dealingwith-unexpected-expenses.htm (accessed August 9, 2020).

${ }^{20} \mathrm{See} \mathrm{https://www.census.gov/content/dam/Census/programs-}$ surveys/ahs/publications/Measuring_Overcrowding_in_Hsg.pdf (accessed August 2, 2020).
} 
lack of paid sick leave exacerbated the impact of Covid-19 on many Hispanic workers and likely contributed to the spread of the virus and its consequences. Covid-19 cases, hospitalization, and death rates among Hispanics are higher than among non-Hispanic whites and some other groups. ${ }^{21}$

\section{What Does the Future Hold?}

Between 1990 and 2020, the Latino population more than doubled. Immigration was the main driver of this growth, but high birthrates among Latino women meant the U.S.-born share of Latinos rose. A sharp slowdown in immigration around the time of the Great Recession further boosted growth in the US-born share of Latinos. Whether Latinos are foreign- or native-born is important; while immigrants may be expected to come in at the bottom and work their way up, the success of second- and third-generation Latinos depends on the effectiveness of U.S. institutions, including education systems and labor markets. Those institutions are tasked with moving Latino children out of the lower working class and into the middle class, minimizing outcome gaps with other groups along the way. If they fail, then that failure should be addressed.

In normal times, and over time, Latinos do relatively well in the labor market, particularly given their relatively low levels of education. Immigrants start out concentrated in the lower income deciles but eventually move up the income ladder. Latino poverty rates, while still significantly higher than those of non-Hispanic whites, have trended down over time and improve markedly in expansions. Recessions, conversely, set Latino families back significantly. The impact of the pandemic recession on Latino poverty is still unknown, but given the severity of the downturn and the spotty safety net, Latino households presumably fell further behind whites, erasing some of the pre-pandemic gains.

Another concern unique to the pandemic recession is the impact on children. With over one-half of Latino children growing up in poor or near-poor households (household income less than 200 percent

\footnotetext{
${ }^{21}$ See https://www.cdc.gov/coronavirus/2019-ncov/covid-data/investigations-discovery/hospitalization-death-byrace-ethnicity.html (accessed October 12, 2020).
} 
of the federal poverty level), their development and well-being were already at risk. ${ }^{22}$ Pandemic-induced school closures and virtual learning models created additional challenges for these children. Latino families may have limited access to computers and the Internet and parents may be unable to help their children with schoolwork. Many low-income children made little educational progress when schools closed or switched to distance learning because of the pandemic. Immigrant families were at a particular disadvantage due to language barriers.

There are other troubling long-run trends that bear watching. One is the rise in non-marital births, which is far more pronounced among Latino women than among non-Hispanic whites. Another is the small but rapidly growing elderly Latino population, which is at risk for chronic health conditions such as diabetes and disability.

Policies that are particularly helpful to Latinos include those that promote immigrant integration, including comprehensive immigration reform. A legalization program would boost earnings and improve working conditions for unauthorized immigrants, which would also benefit their families. Living with unauthorized status has become harder over time in the U.S. as the government has cracked down more on employers who hire unauthorized workers and also on unauthorized immigrants themselves, such as preventing them from obtaining driver's licenses.

Education reform, including broadening eligibility and scope of pre-K programs, would help Latinos since so many are children whose parents have little education and limited English proficiency. English language instruction, for both children and adults, is an important factor for both higher earnings and lower poverty (Orrenius and Zavodny 2013a). Lastly, Latinos have low rates of health insurance coverage. While they are relatively young and healthy on average, the pandemic has shown how Latinos can still be disproportionately harmed by disease, a fact made worse by the lack of health insurance and

\footnotetext{
${ }^{22}$ See https://www.hispanicresearchcenter.org/research-resources/an-economic-portrait-of-low-income-hispanicfamilies-key-findings-from-the-first-five-years-of-studies-from-the-national-research-center-on-hispanic-childrenfamilies/ (accessed October 12, 2020).
} 
limited access to health care. As the United States recovers from the pandemic, these issues will require policymakers' attention if the country wants to ensure that a rising tide lifts all boats. 


\section{References}

Aaronson, Stephanie, Mary C. Daly, William L. Wascher, and David W. Williams. 2019. Okun revisited: Who benefits most from a strong economy? Brookings Papers on Economic Activity 333-375.

Addo, Fenaba R., and William A. Darity, Jr. 2021. Wealth, race, and the working class from 2010-2019. Forthcoming in Annals of the AAPSS.

Alsan, Marcella, and Crystal Yang. 2018. Fear and the safety net: Evidence from Secure Communities. National Bureau of Economic Research Working Paper No. 24731. https://doi.org/10.3386/w24731

Borjas, George J., and Hugh Cassidy. 2020. The adverse effect of the Covid-19 labor market shock on immigrant employment. National Bureau of Economic Research Working Paper No. 27243. https://doi.org/10.3386/w27243

Congressional Budget Office. 2007. The impacts of unauthorized immigrants on the budgets of state and local governments. Washington, DC: Congressional Budget Office.

Couch, Kenneth A., Robert Fairlie, and Huanan Xu. 2018. Racial differences in labor market transitions and the Great Recession. Research in Labor Economics 46: 1-53. https://doi.org/10.1108/S0147-912120180000046001

Duncan, Brian, and Stephen J. Trejo. 2018a. Identifying the later-generation descendants of U.S. immigrants: Issues arising from selection ethnic attrition. Annals of the AAPSS 677: 131-138. https://doi.org/10.1177/0002716218763293

Duncan, Brian, and Stephen J. Trejo. 2018b. Socioeconomic integration of U.S. immigrant groups over the long term: The second generation and beyond. National Bureau of Economic Research Working Paper No. 24394. https://doi.org/10.3386/w24394

Fairlie, Robert W., Kenneth Couch, and Huanan Xu. 2020. The impacts of Covid-19 on minority unemployment: First evidence from April 2020 CPS microdata. National Bureau of Economic Research Working Paper No. 27246. https://doi.org/10.3386/w27246

Montenovo, Laura, Xuan Jiang, Felipe Lozano Rojas, Ian M. Schmutte, Kosali I. Simon, Bruce A. Weinberg, and Coady Wing. 2020. Determinants of disparities in Covid-19 job losses. National Bureau of Economic Research Working Paper No. 27132. https://doi.org/10.3386/w27132

National Academies of Sciences, Engineering, and Medicine. 2015. The Integration of Immigrants into American Society. Panel on the Integration of Immigrants into American Society, M. C. Waters and M. G. Pineau, eds. Committee on Population. Division of Behavioral and Social Sciences and Education. Washington, DC: The National Academies Press. https://doi.org/10.17226/21746

Orrenius, Pia M., and Madeline Zavodny. 2010. Mexican immigrant employment outcomes over the business cycle. American Economic Review: Papers \& Proceedings 100 (2): 316-320. https://doi.org/10.1257/aer.100.2.316

Orrenius, Pia M., and Madeline Zavodny. 2013a. How immigrants and U.S. natives fare during recessions and recoveries. In Immigrants in a Changing Labor Market: Responding to Economic Needs, ed. Michael Fix, Demetrios G. Papademetriou, and Madeleine Sumption. Washington, DC: Migration Policy Institute, pp. 123-166.

Orrenius, Pia M., and Madeline Zavodny. 2013b. Trends in poverty and inequality among Hispanics. In The Economics of Inequality, Poverty, and Discrimination in the $21^{\text {st }}$ Century, vol. I, ed. Robert S. Rycroft. Santa Barbara, CA: Praeger, pp. 217-235. 
Orrenius, Pia M., and Madeline Zavodny. 2019. Employment among US Hispanics: A tale of three generations. Journal of Economics, Race, and Policy 2: 3-19. https://doi.org/10.1007/s41996-018-0021-9

Peri, Giovanni, and Zachariah Rutledge. 2020. Revisiting economic assimilation of Mexican and Central Americans immigrants in the United States. Institute of Labor Economics Discussion Paper No. 12976.

Thompson, Jeffrey P., and Gustavo A. Suarez. 2017. Updating the racial wealth gap. Board of Governors of the Federal Reserve System Working Paper No. 2015-76. https://doi.org/10.17016/FEDS.2015.076r1

Watson, Tara. 2014. Inside the refrigerator: Immigration enforcement and chilling effects in Medicaid participation. American Economic Journal: Economic Policy 6(3): 313-338. https://doi.org/10.1257/pol.6.3.313 


\section{APPENDIX FIGURE 1 Latinos Are the Largest Working-Class Minority Group in the United States}
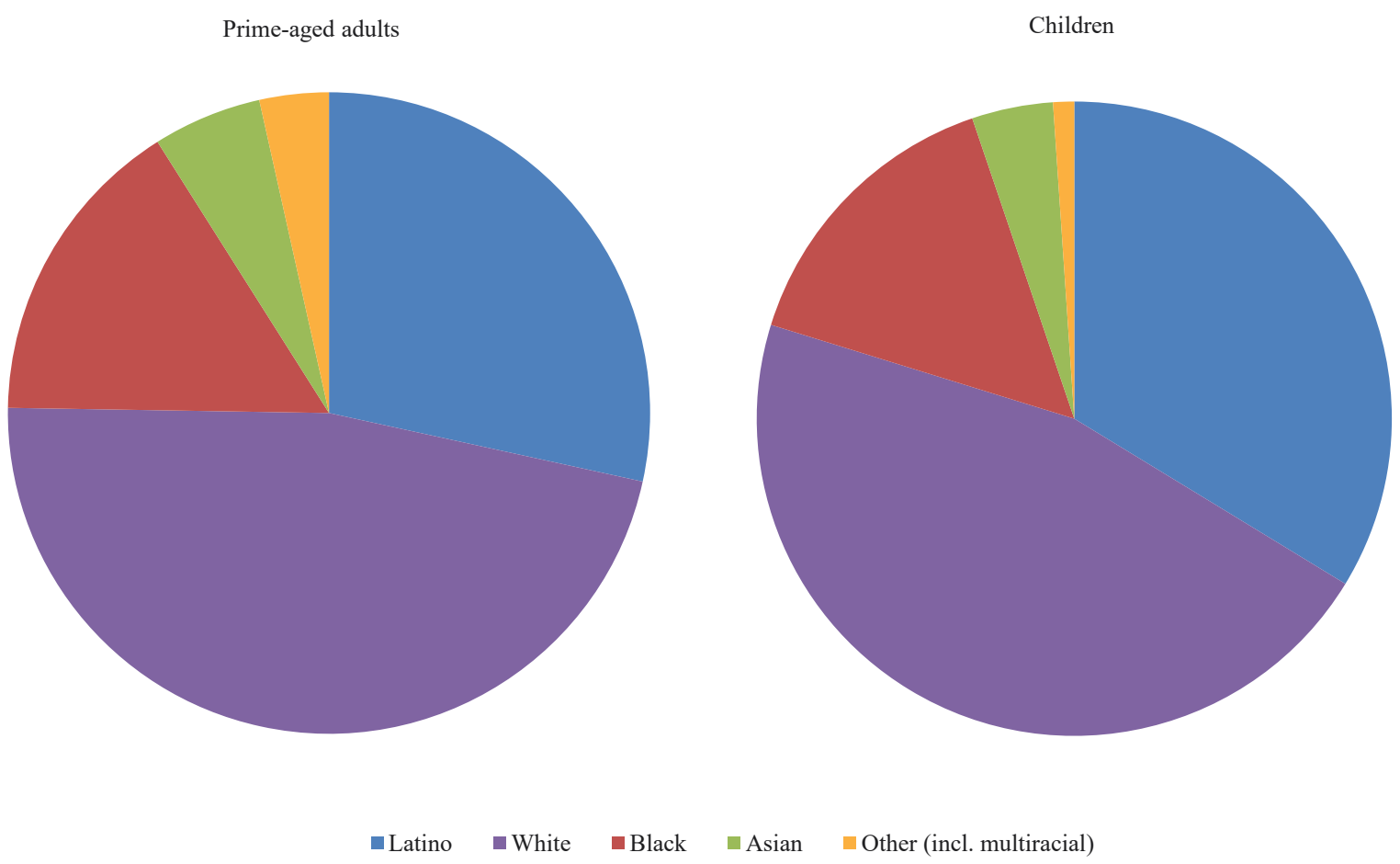

NOTE: Authors' calculations using 2020 CPS ASEC data from IPUMS. The sample only includes people living in households headed by a prime-aged adult that are in the second through fourth deciles of the overall income distribution.

\section{APPENDIX TABLE 1 \\ Working-Class Latinos Have Less Education, Larger Households than Working-Class Non- Hispanic Whites}

\begin{tabular}{lccc}
\hline & \multicolumn{2}{c}{ Hispanic } & Non-Hispanic \\
\cline { 2 - 3 } & Immigrant & U.S. native & \\
\hline Age & 41.9 & 37.0 & 41.1 \\
Married & 0.70 & 0.49 & 0.54 \\
Male & 0.48 & 0.44 & 0.47 \\
Mexican-descent & 0.64 & 0.71 & -- \\
Highest education level: & & & \\
Less than high school graduate & 0.44 & 0.15 & 0.08 \\
High school graduate & 0.34 & 0.37 & 0.36 \\
Some college & 0.13 & 0.34 & 0.33 \\
Bachelor's degree or higher & 0.09 & 0.14 & 0.23 \\
Number of hhld members & 4.0 & 3.7 & 3.2 \\
Number of children in hhld & 0.78 & 0.75 & 0.65 \\
Household income previous year & $\$ 45,000$ & $\$ 46,100$ & $\$ 45,000$ \\
\hline NOTE: Ans
\end{tabular}

NOTE: Authors' calculations using 2020 CPS ASEC data from IPUMS. Only prime-aged adults in working-class households (households headed by a prime-aged adult that are in the second through fourth deciles of the overall income distribution) are included. Median household income is shown; the other variables are means or shares. 


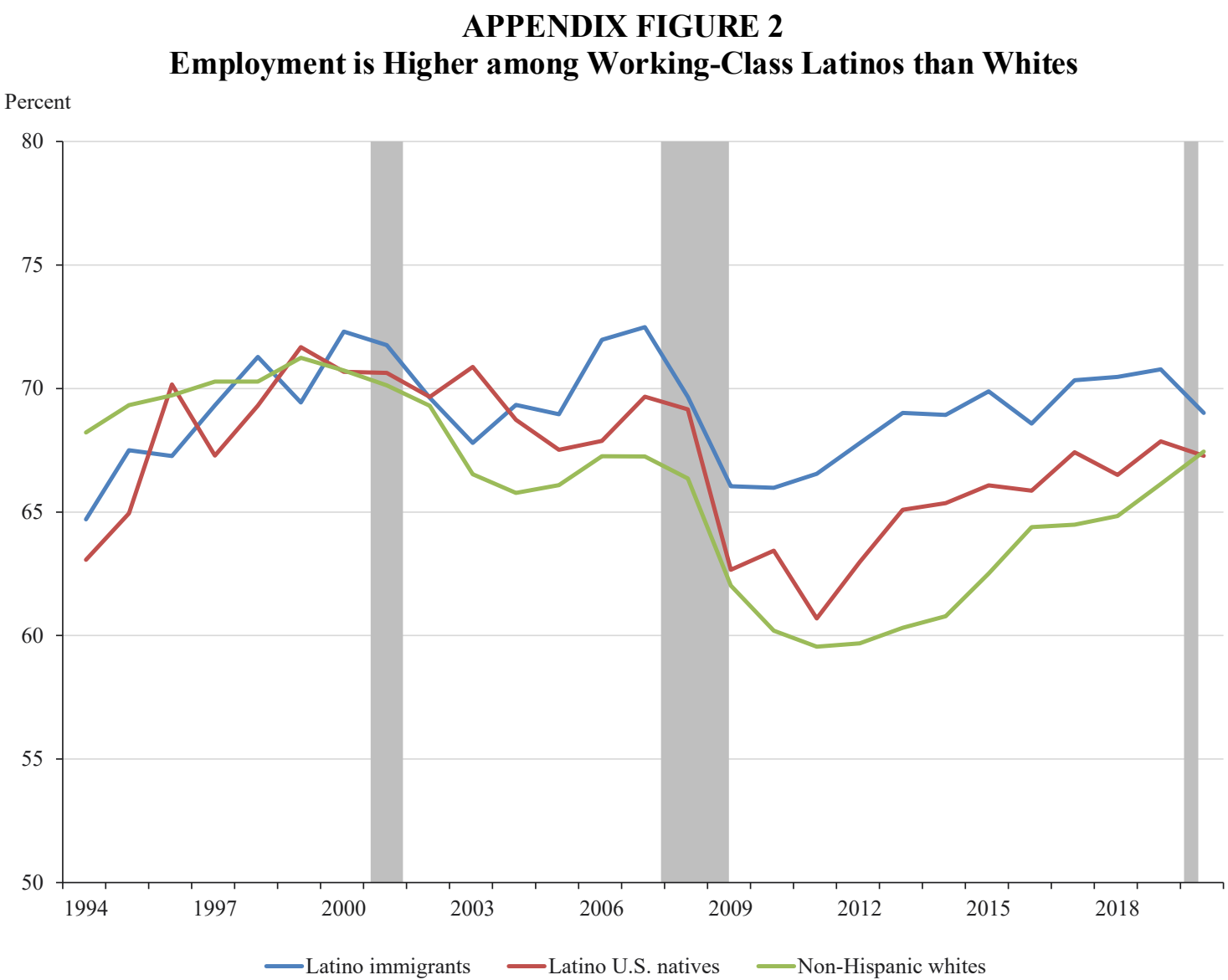

NOTE: Shown is the share of civilian adults ages 25-59 who are employed. The sample is conditional on living in a household with a prime-aged head that was in the second through fourth deciles of the income distribution the previous calendar year. Authors' calculations using 1994-2020 CPS ASEC data from IPUMS. 
APPENDIX FIGURE 3

Unemployment Rates Are Similar across Ethnicities among the Working Class

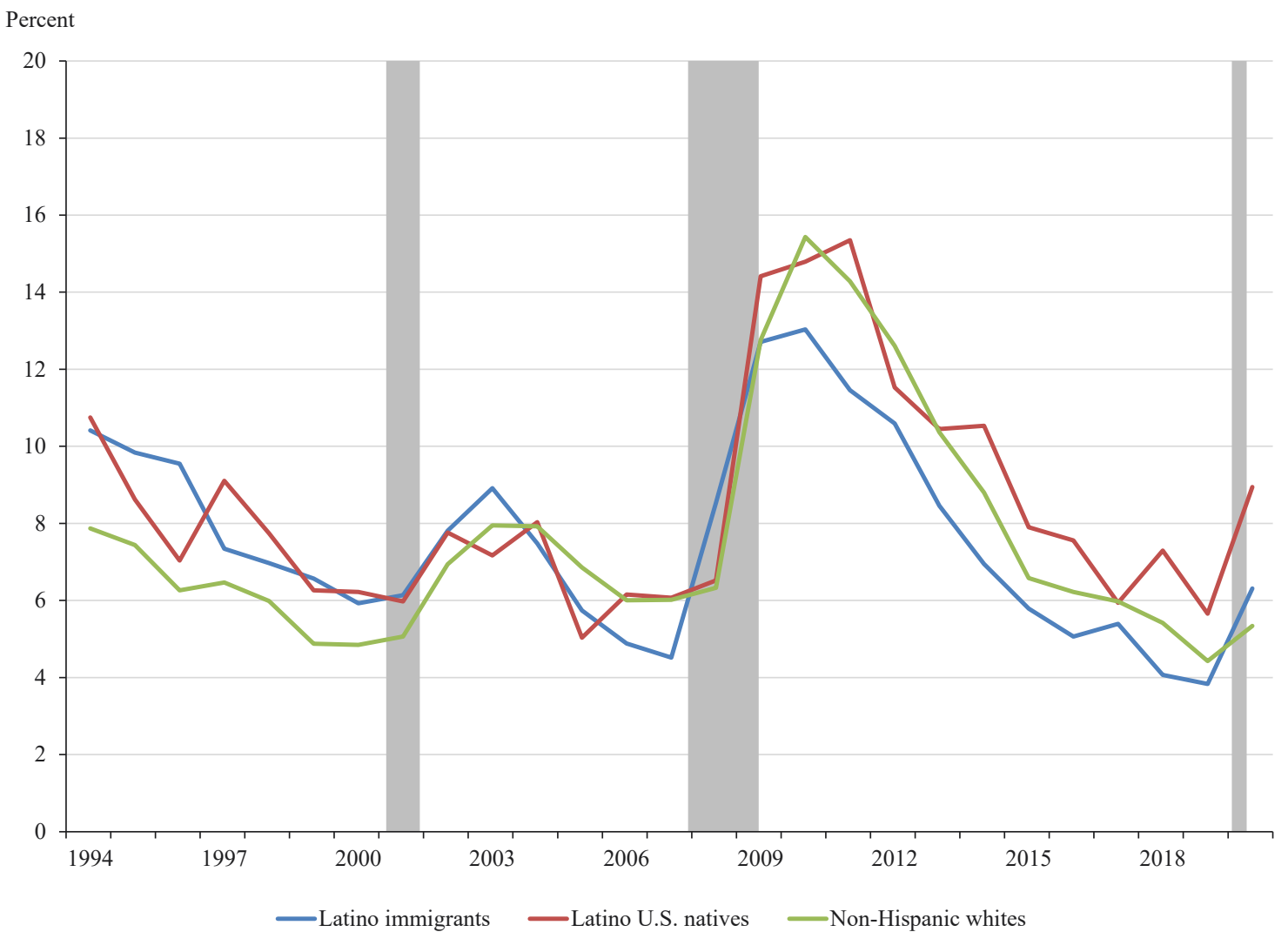

NOTE: Shown is the share of civilian adults ages 25-59 who are unemployed, conditional on being in the labor force. The sample is conditional on living in a household with a prime-aged head that was in the second through fourth deciles of the income distribution the previous calendar year. Authors' calculations using 1994-2020 CPS ASEC data from IPUMS. 
APPENDIX FIGURE 4

Real Hourly Earnings Are Lower for Latinos than non-Hispanic Whites

Real hourly wage

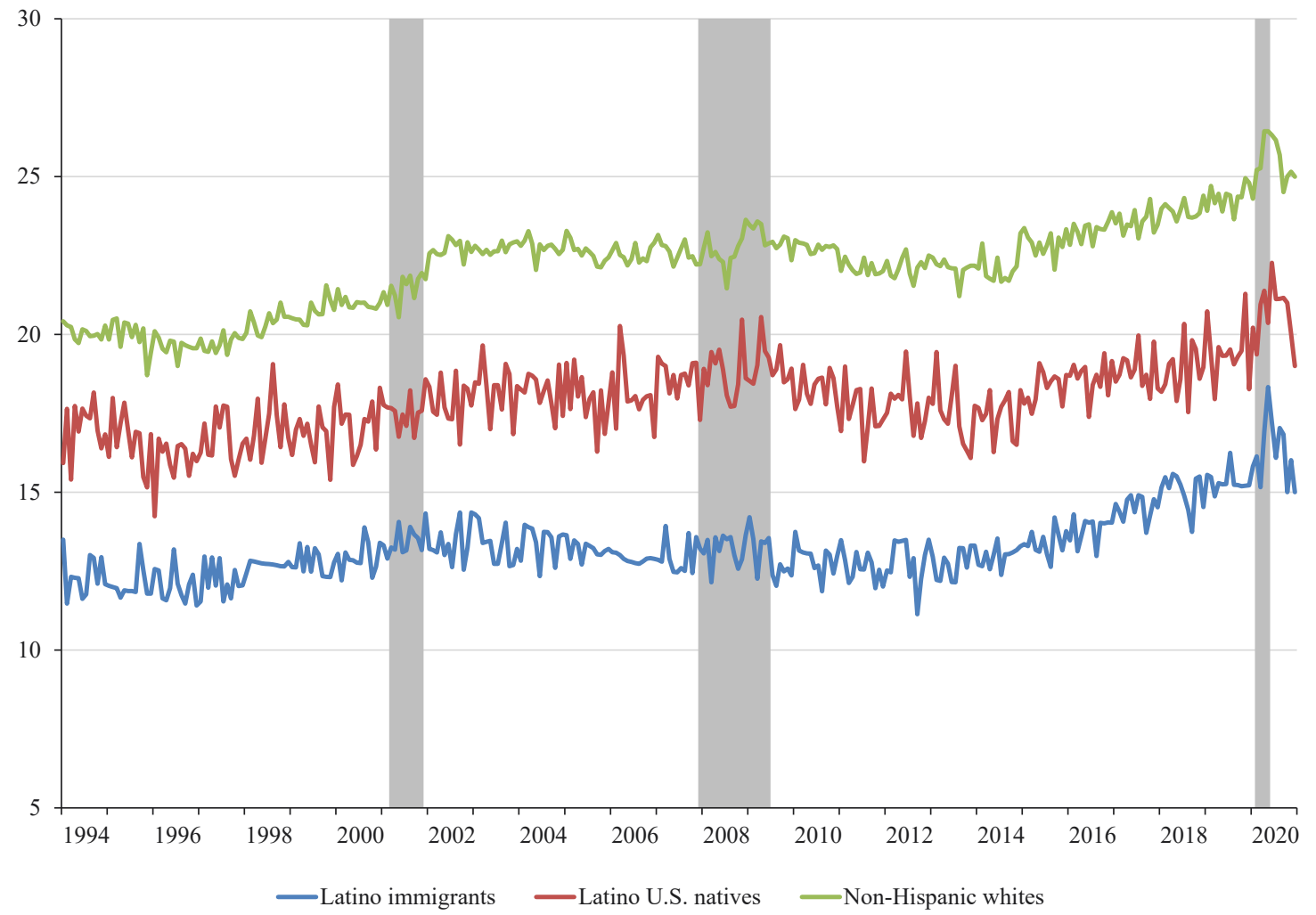

NOTE: Shown is median real hourly earnings for civilian adults ages 25-59 with positive earnings. Earnings are deflated using the CPI-W (December $2020=100)$. Workers with imputed earnings are not included. Authors' calculations using January 1994December 2020 CPS basic monthly files data from IPUMS. 
APPENDIX FIGURE 5

Real Hourly Earnings Are Lower for Working-Class Latino Immigrants

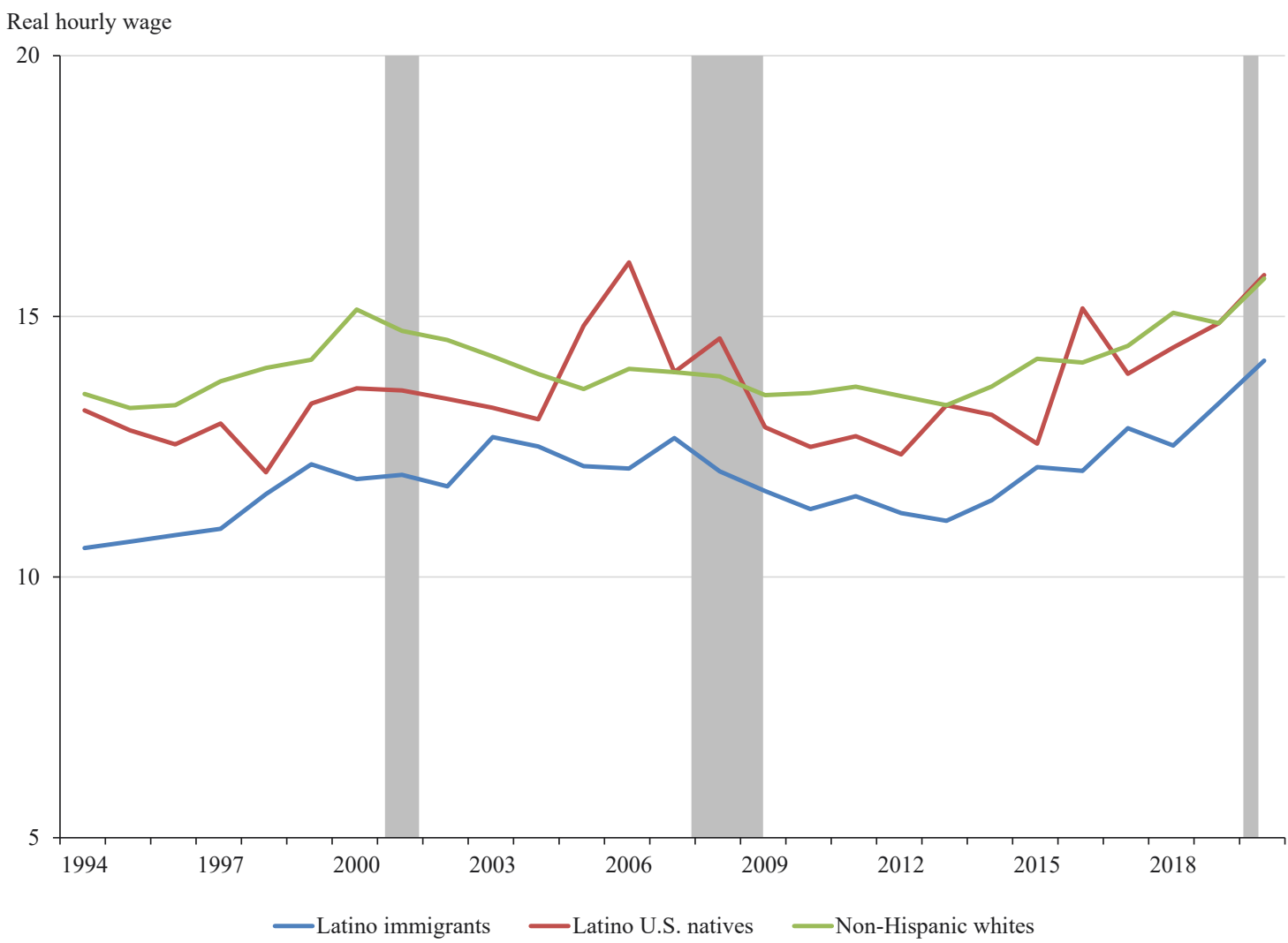

NOTE: Shown is median real hourly earnings for civilian adults ages 25-59 with positive earnings. Earnings are deflated using the CPI-W (December $2020=100$ ). Workers with imputed earnings are not included. The sample is conditional on living in a household with a prime-aged head that was in the second through fourth deciles of the income distribution the previous calendar year. Authors' calculations using 1994-2020 CPS ASEC data from IPUMS. 
APPENDIX FIGURE 6

Poverty Rates Are More Cyclical for Working-Class Latino Households

Percent

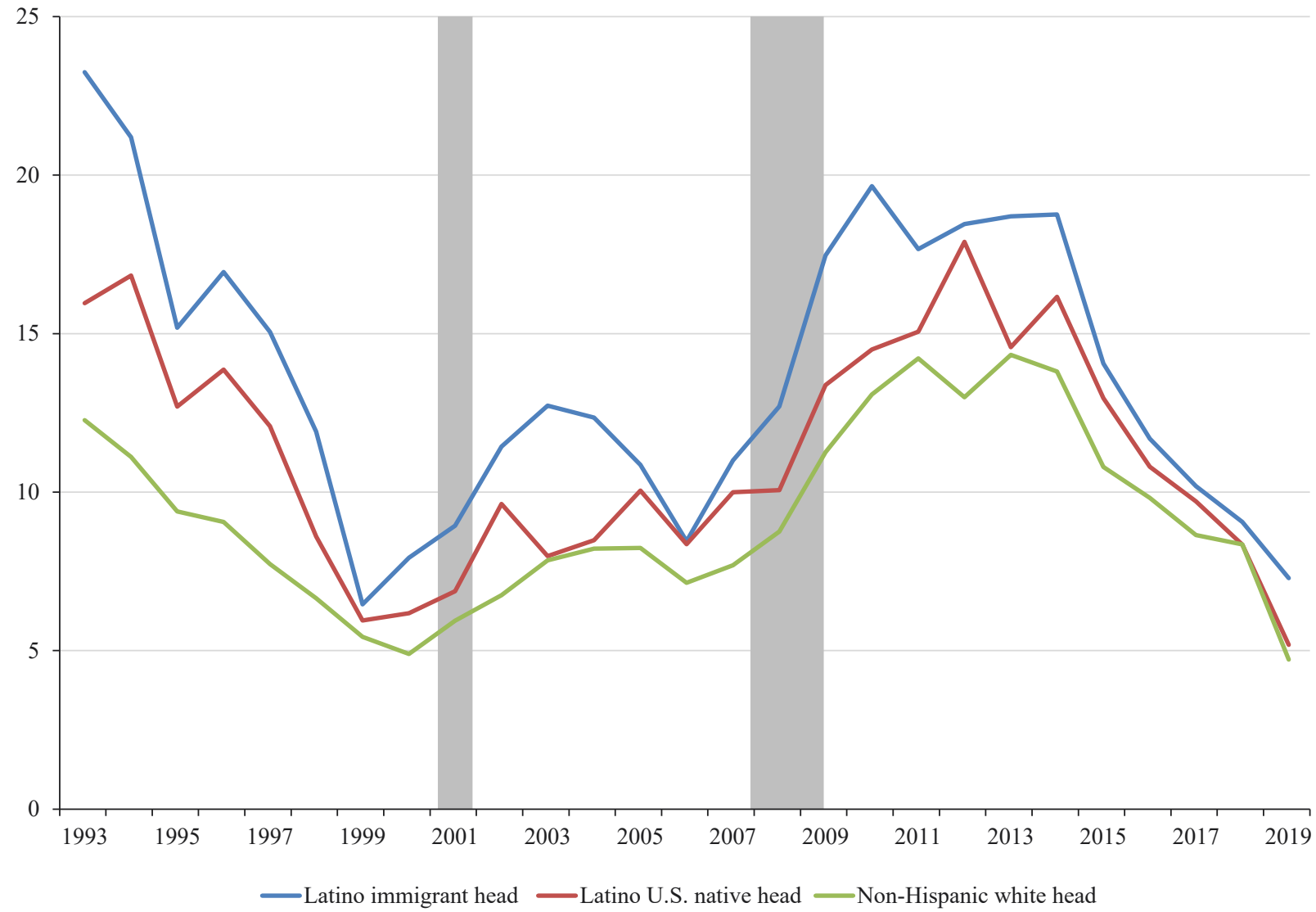

NOTE: Shown is the share of households in the second through fourth deciles of the overall income distribution with a primeaged head in the indicated group classified as poor based on federal poverty guidelines. Authors' calculations from 1994-2020 CPS ASEC data from IPUMS using household income for the year indicated (the calendar year prior to the ASEC survey year). 